\title{
pH Variations and Chemometric Assessment of Borehole Water in Orji, Owerri Imo State, Nigeria
}

\author{
Christian Ebere Enyoh $^{1^{*}}$, Andrew Wirnkor Verla ${ }^{1}$ and Ngozi Jane Egejuru ${ }^{2}$ \\ ${ }^{1}$ Group Research in Analytical Chemistry, Environment and Climate Change, Department of Chemistry, Imo State University PMB 2000, Owerri, Imo State, Nigeria
}

${ }^{2}$ Out Patient Department (OPD) Unit, Federal Medical Centre, Owerri, Imo State, Nigeria

*Corresponding author: Christian Ebere Enyoh, Group Research in Analytical Chemistry, Environment and Climate Change, Department of Chemistry, Imo State University PMB 2000, Owerri, Imo State, Nigeria, Tel: 2347063715081; E-mail: cenyoh@gmail.com

Received date: April 09, 2018; Accepted date: April 18, 2018; Published date: April 24, 2018

Copyright: (c) 2018 Enyoh CE, et al. This is an open-access article distributed under the terms of the Creative Commons Attribution License, which permits unrestricted use, distribution, and reproduction in any medium, provided the original author and source are credited.

\begin{abstract}
Inhabitants of Orji are still pending on borehole water for drinking water without any treatment. The storage of this water in household containers for a long time as well as the handling might lead to a quality deteriorated and become unsuitable for human consumption. The study therefore evaluated the effect of long storage on $\mathrm{pH}$ values as well as determined the total concentrations of $\mathrm{Ni}, \mathrm{Cd}, \mathrm{Cu}, \mathrm{Pb}$ and $\mathrm{Fe}$ in 10 borehole water samples from Orji. The $\mathrm{pH}$ was determined using Jenway $3510 \mathrm{pH}$ meter while Perkins Elmer Analyst Atomic Absorption Spectrophometer was used for heavy metals determination after acid digestion. The results obtained were compared to National Agency for Food Drugs and Control (NAFDAC) and Standard Organization of Nigeria (SON) standard and were chemometrically assessed. The mean concentrations of the studied metals were below standard. $\mathrm{pH}$ continually increased with storage but did not exceed the standard range of (6.3/6.5-8.5) set by SON/NAFDAC over 12 weeks. Chemometric assessment such as linear regression analysis revealed positive association between $\mathrm{pH}$ values and metal concentration. The association were in the order of significant $\mathrm{pH} / \mathrm{Fe}(0.202)>\mathrm{pH} / \mathrm{Cd}(0.169)>\mathrm{pH} / \mathrm{Ni}$ $(0.161)>\mathrm{pH} / \mathrm{Pb}(0.123)$ respectively. Spearman's correlation revealed similar source(s) of contamination of the studied metals except for Fe. Coefficient of Variation (CV) showed low variability $(<20)$. Contamination Factor (CF) showed low contamination $(<1)$, except for Cadmium which showed moderate to considerable contamination. Pollution Load Index (PLI) showed no pollution $(<1)$ while mean WQI revealed "poor quality water" with WQI of 100.5 based on the studied metals. Therefore, precaution should be taken when consuming stored borehole water from Orji.
\end{abstract}

Keywords: Groundwater; Chemometrics; Risk; Pollution; Regression; Health

\begin{abstract}
Abbreviations:
NAFDAC: National Agency for Food Drugs and Control; SON: Standard Organization of Nigeria; CV: Coefficient of Variation; PLI: Pollution Load Index; WQI: Water Quality Index; CF: Contamination Factor; LRM: Linear Regression Model; EWQ: Excellent Water Quality; GWQ: Good Water Quality; PWQ: Poor Water Quality; VPWQ: Very Poor Water Quality; UnSFD: Unsuitable for Drinking.
\end{abstract}

\section{Introduction}

Of all the gifts of nature, water is only second in importance to the air we breathe [1]. Therefore protecting our water is paramount and important for the present and future generations. Unfortunately, groundwater source is threatened because it flows slowly through the subsoil, the human activities impact may affect the groundwater for a long time. This means that the pollution which occurred decades ago may still threaten water quality nowadays and in some cases will continue to do so for several generations [2].

Among the many available water sources for use in Nigeria, groundwater is thought to be most safe for consumption. Timothy [2] considered groundwater to be "a hidden resource" which is quantitatively more important than surface water. This has prompted the continuous drilling of borehole in almost all communities in
Nigeria. A recent survey has shown that $80 \%$ of boreholes in a locality in Nigeria are privately-owned and are selling water to the public $[3,4]$. The public buys the water and store them at home in jerry-cans, kegs, bowl and drums for later use. This practice is scientifically unacceptable. Earlier studies confirmed significant deterioration of the water quality during its storage at home in rural and urban areas throughout Africa, Asia and Latin America [5-8]. This deterioration in the water quality could pose serious health issue to the consumer.

The emphasis on existing studies is on the general physicochemical and biological properties. However, information on $\mathrm{pH}$ variations and its association with heavy metals in borehole water is lacking in this regard. The two parameters are very important when assessing drinking water quality. $\mathrm{pH}$ simply tell how acidic or alkaline a substance is. Therefore, drinking water whose $\mathrm{pH}$ is significantly altered can lead to a condition of acidiosis and alkaliosis. These conditions can cause arrhythmia or irregular heartbeats, imbalanced electrolyte levels and coma. On the other hand, heavy metals are ubiquitous and their problems in the environment cannot be overemphasized. High concentration of heavy metals in the environment can be detrimental to a variety of living systems. Excessive ingestion of these metals by humans can cause poisoning, cancer, nervous system damage and ultimately death $[9,10]$. Although, the organs/systems affected and the severity of the toxicity vary with the particular heavy metal involved, the chronicity and extent of the exposure and the age of the individual [11]. The mobility and availability of heavy metals in the water is a function $\mathrm{pH}$ and some other physicochemical parameters [12]. 
A sectional study by Duru [13] on borehole water samples collected in Orji mechanic village and recorded concentrations of $\mathrm{Ni}, \mathrm{Cd}, \mathrm{Pb}, \mathrm{Cu}$ and Fe below SON standards. However, the borehole water is of poor quality with Water Quality Index (WQI) of 153.33 [13]. In the present study, we determined the total concentration of $\mathrm{Ni}, \mathrm{Cd}, \mathrm{Pb}, \mathrm{Cu}, \mathrm{Fe}$ in borehole water samples in Orji and also measured the $\mathrm{pH}$ values over a period of 12 weeks. These metals are selected based on the classification of United State Environmental Pollution Agency as priority pollutants [14]. The data collected were assessed chemometrically. Chemometrics is simply the science of relating measurements made on a chemical system or process to the state of the system via application of mathematical or statistical methods/models [15]. The models used were CF, PLI and WQI to assess the contamination/pollution and quality status of the water. Also, Linear Regression Model (LRM) was used to find out how the $\mathrm{pH}$ values relate with heavy metal concentrations. This is very helpful in interpreting or extracting concise information from a large environmental data for easy understanding by policy makers.

\section{Materials and Methods}

\section{Study area}

The study area is Orji which is located in Owerri North Local Government Area of Imo State. Geographically, the area falls between coordinates of latitude $5.24-5.270 \mathrm{~N}$ and longitude $7.04-7.060 \mathrm{E}$. The geology of the area consists of plain soil which is about $0.05-2.0 \mathrm{~mm}$ in size and it is rather deep, porous, infertile and highly leached [13]. The area contains markets which generate lots of waste daily. In addition, an automechanic activity is one major activity carried out within the area. It is worthy of note that over $50 \%$ of Orji inhabitant rely on groundwater without treatment for their domestic activities majorly cooking and as drinking water. Satellite map showing study area and sample locations are presented in Figure 1.

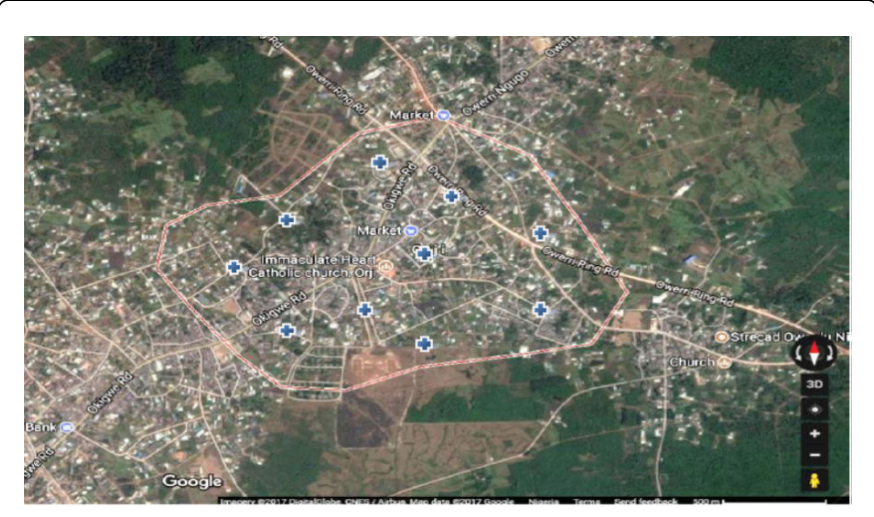

Figure 1: Satellite map showing Orji area and sample locations.

\section{Sampling and sample collection}

10 borehole water samples were randomly collected and sample point were spread objectively within the study area. The water samples were collected using cleaned plastic bottles from taps connected to the borehole. Three samples were collected from each location at the interval of two hours and mixed together to make a composite sample. The plastic bottles used were properly labeled and cleaned prior to sample collection by soaking it in $10 \% \mathrm{HCl}$ for 48 hours, washed and rinsed with deionized water and dried.

\section{Heavy metals determination}

The methods of Ibe [16] were used, but modified for the analysis. The samples were digested with a mixture of Nitric and Perchloric acid. $2 \mathrm{ml}$ of the sample was accurately weighed into a beaker and then 10 $\mathrm{ml}$ of $\mathrm{HNO}_{3}$ and $5 \mathrm{ml}$ of $\mathrm{HClO}_{4}$ was added then it was allowed to stand for 24 hours. This was followed by filtration into a $100 \mathrm{ml}$ volumetric flask and filtrate was made up to mark and used for analysis. The concentrations of metals were determined using Perkin Elmer AAnalyst 400 Atomic Absorption Spectrophotmeter. The results were compared with SON and NAFDAC standards.

\section{pH determination}

The $\mathrm{pH}$ values were determined using Jenway $3510 \mathrm{pH}$ Meter. The water samples were tested immediately for $\mathrm{pH}$ after collection. The $\mathrm{pH}$ probe was inserted into $50 \mathrm{ml}$ (collected from the large sample) of the water sample until stable reading is displayed on the meter screen. This was done for the 10 samples and throughout the study period. The meter was always calibrated each week prior to analysis for that week. The borehole water samples were kept at ambient temperature during the study period.

\section{Data analysis and chemometric assessment}

Data analysis was calculated using coupled Microsoft Excel $2009+$ Analyse-it ${ }^{\oplus}$ v2.2 (2010). ANOVA was employed for the purpose of testing metal concentrations for statistically significant differences described when $\mathrm{P}<0.05$ at $5 \%$ significance level. Spearman's CORRELL was done on heavy metals to check for association. Other chemometric assessments were done using index models such as CF, PLI, WQI, Variability (\%) and LRM analysis. Graphical representation were also employed were appropriate.

\section{Results and Discussion}

The result obtained for the heavy metal analysis is presented in Table 1. The result for ANOVA showed there were no significant differences $(p<0.05)$ between metal concentrations. These suggest that the metal concentrations in the different borehole water samples are similar which might due to the same geographical location and similar anthropogenic activities around the area. The concentrations of Nickel in the ten samples were below the SON threshold limit (0.02) for drinking water. Similarly Cadmium concentrations were generally low except for samples F (0.009) and J (0.008) which were higher than the threshold of 0.003 set by SON/NAFDAC. Cadmium is present almost everywhere in our environment. Once absorbed in the body, they are primarily toxic to the kidney, especially to the proximal tubular cells, the main site of accumulation. They also cause bone demineralization, either through direct bone damage or indirectly as a result of renal dysfunction [17]. All other studied metals were below the SON/ NAFDAC threshold limit, which suggest that the borehole water in the study area is not yet contaminated. The findings here are similar to the findings of Duru [13]. 
Citation: Enyoh CE, Verla AW, Egejuru NJ (2018) pH Variations and Chemometric Assessment of Borehole Water in Orji, Owerri Imo State,

Page 3 of 9

\begin{tabular}{|c|c|c|c|c|c|c|c|c|c|c|c|c|c|}
\hline \multirow[b]{2}{*}{ Metal symbol } & \multicolumn{10}{|c|}{ Concentrations of metals in various Samples } & \multirow[b]{2}{*}{ Mean \pm SD } & \multirow[b]{2}{*}{ son } & \multirow[b]{2}{*}{ NAFDAC } \\
\hline & A & B & C & D & E & $\mathbf{F}$ & G & $\mathrm{H}$ & 1 & $\mathbf{J}$ & & & \\
\hline $\mathrm{Ni}(\mathrm{mg} / \mathrm{kg})$ & 0 & 0 & 0.003 & 0 & 0 & 0.002 & 0 & 0 & 0.001 & 0.014 & $0.002 \pm 0.04$ & 0.02 & - \\
\hline $\mathrm{Cd}(\mathrm{mg} / \mathrm{kg})$ & 0.0005 & 0.0004 & 0 & 0 & 0.002 & 0.009 & 0.00006 & 0 & 0 & 0.008 & $0.002 \pm 0.003$ & 0.003 & 0.003 \\
\hline $\mathrm{Pb}(\mathrm{mg} / \mathrm{kg})$ & 0 & 0 & 0.001 & 0 & 0 & 0 & 0 & 0 & 0 & 0.001 & $0.0002 \pm 0.000$ & 0.01 & 0.01 \\
\hline $\mathrm{Cu}(\mathrm{mg} / \mathrm{kg})$ & 0.034 & 0.047 & 0.11 & 0.015 & 0 & 0.072 & 0.001 & 0.021 & 0.096 & 0.41 & $0.081 \pm 0.12$ & 1 & 1 \\
\hline $\mathrm{Fe}(\mathrm{mg} / \mathrm{kg})$ & 0.167 & 0.041 & 0.003 & 0.012 & 0.004 & 0.065 & 0.01 & 0.021 & 0.11 & 0 & $0.043 \pm 0.053$ & 0.3 & 0.3 \\
\hline
\end{tabular}

Table 1: The result for the heavy metal analysis for the 10 borehole water samples analyzed.

For the purpose of comparing the distribution of metal The highest concentration was recorded in J followed by C ( $0.003 \mathrm{mg} /$ concentration between the different samples, cone plot were created. $\mathrm{kg})$, then $\mathrm{F}(0.002 \mathrm{mg} / \mathrm{kg})$ and I $(0.001 \mathrm{mg} / \mathrm{kg})$. The mean The plotted distribution is presented in Figures 2a-2e. Nickel concentration of Nickel was $0.002 \mathrm{mg} / \mathrm{kg}$. concentration was 0.00 in samples A, B, D, E, G, and $\mathrm{H}$ respectively.

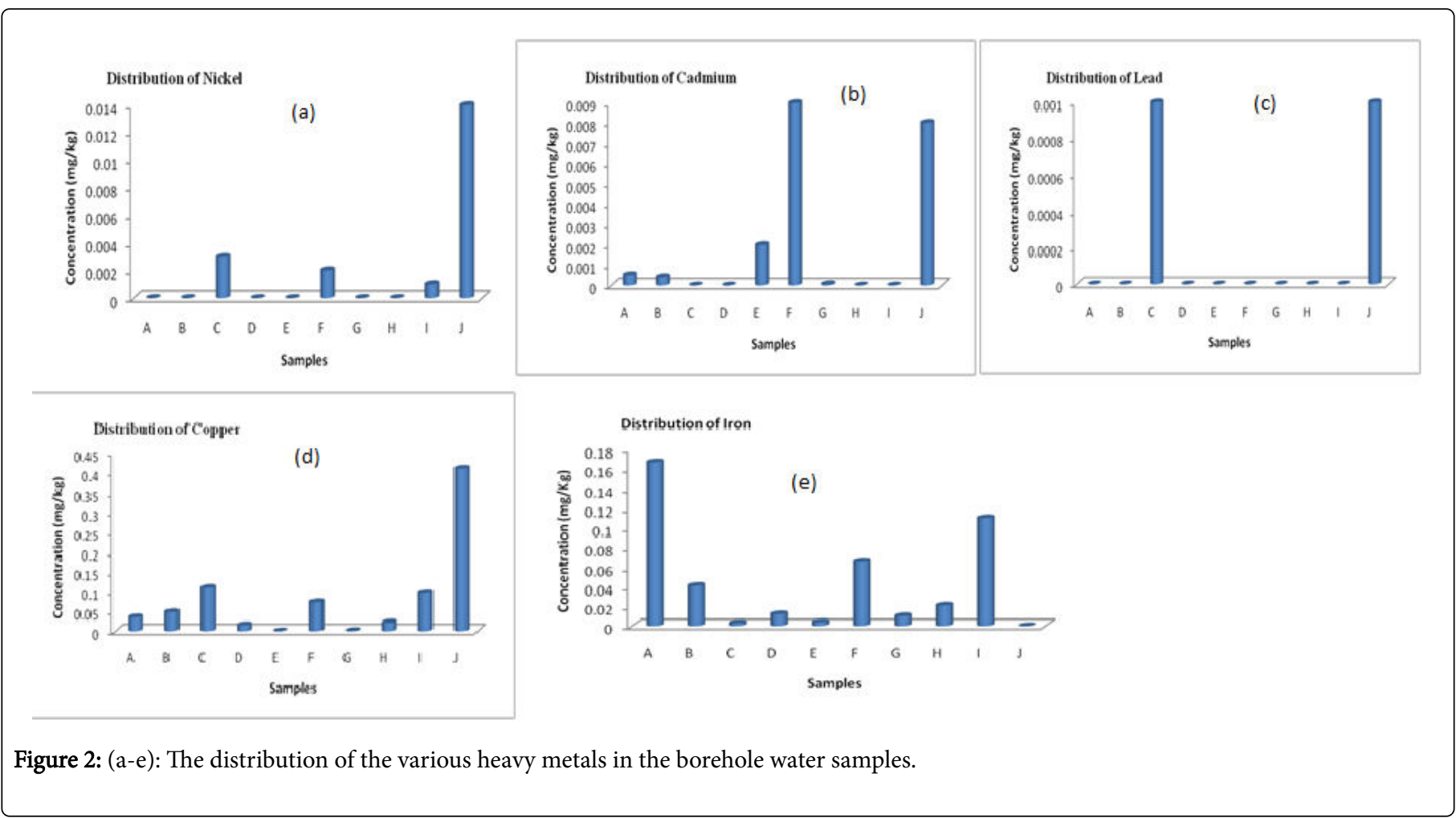

The order for Cadmium was $\mathrm{F}(0.009 \mathrm{mg} / \mathrm{kg})>\mathrm{J}(0.008 \mathrm{mg} / \mathrm{kg})>\mathrm{E}$ $(0.002 \mathrm{mg} / \mathrm{kg})>\mathrm{A} \quad(0.0005 \mathrm{mg} / \mathrm{kg})>\mathrm{B} \quad(0.0004 \mathrm{mg} / \mathrm{kg})>\mathrm{G} \quad(0.00006$ $\mathrm{mg} / \mathrm{kg}$ ) respectively. The concentration in $\mathrm{D}$ and $\mathrm{H}$ was $0.000 \mathrm{mg} / \mathrm{kg}$. Lead concentrations were $0.0001 \mathrm{mg} / \mathrm{kg}$ in $\mathrm{C}$ and $\mathrm{J}$, while $0.000 \mathrm{mg} / \mathrm{kg}$ in other samples. The distribution of Copper was $\mathrm{J}>\mathrm{I}>\mathrm{C}>\mathrm{F}>\mathrm{B}>\mathrm{A}>\mathrm{H}$ respectively while Iron was $\mathrm{A}>\mathrm{I}>\mathrm{F}>\mathrm{B}>\mathrm{D}>\mathrm{G}>\mathrm{E}>\mathrm{C}$ respectively.

\section{Contamination Factor (CF) and Pollution Load Index (PLI)}

The mathematical expression ( 1 and 2 ) was used for calculating the CF and PLI respectively [17]. The CF reveals the extent of contamination of the individual metals while the PLI reveals the pollutants/contaminant load in the borehole water sample. In other words, it provides a simple and comparative means for assessing the overall level of pollution/contamination in a sample.

$$
\mathrm{CF}=\mathrm{C}_{\mathrm{m}} / \mathrm{C}_{\mathrm{b}}(1)
$$

Where, $C_{m}=$ concentration of the metal in the water; $C_{b}=$ reference concentration of the metal.

SON standards for heavy metals in drinking water were taken as the reference concentration. The values were presented in Table 1.

$$
\mathrm{PLI}=\left(\mathrm{CF}_{1} \times \mathrm{CF}_{2} \times \mathrm{CF}_{3} \ldots . . \mathrm{CF}_{\mathrm{n}}\right)^{1 / \mathrm{n}}(2)
$$

Where, $n=$ number of metals considered in the study; $\mathrm{CF}_{\mathrm{i}}=$ Contamination Factor for each individual metal. 
Citation: Enyoh CE, Verla AW, Egejuru NJ (2018) pH Variations and Chemometric Assessment of Borehole Water in Orji, Owerri Imo State,

Page 4 of 9

The computational results for CF and PLI are presented in Table 2. The $\mathrm{CF}<1$ represents "low contamination", $1 \leq \mathrm{CF}<3$ represents "moderate contamination", $3 \leq \mathrm{CF}<6$ represents "considerable contamination", and $6 \leq \mathrm{CF}$ represents "very high contamination" [13]. All samples recorded low contamination $(\mathrm{CF}<1)$ except for $\mathrm{CF}_{\mathrm{Cd}}$ in samples F (3.00) and J (2.67), which showed moderate to considerable contamination. Cadmium can be retained efficiently in the body and the prime target organ is the kidney. Therefore, consumption of water samples F and J could pose serious issue to the consumer's kidney.

\begin{tabular}{|c|c|c|c|c|c|c|c|c|c|c|}
\hline \multirow{2}{*}{$\begin{array}{l}\text { Metal } \\
\text { symbol }\end{array}$} & \multicolumn{10}{|c|}{ Samples } \\
\hline & A & B & C & D & $\mathrm{E}$ & $\mathbf{F}$ & G & H & 1 & $J$ \\
\hline CFNi & 0 & 0 & 0.15 & 0 & 0 & 0.1 & 0 & 0 & 0.05 & 0.7 \\
\hline CFCd & 0.17 & 0.13 & 0 & 0 & 0.67 & 3 & 0.02 & 0 & 0 & 2.67 \\
\hline CFPb & 0 & 0 & 0.1 & 0 & 0 & 0 & 0 & 0 & 0 & 0.1 \\
\hline CFCu & 0.03 & 0.05 & 0.11 & 0.02 & 0 & 0.07 & 0 & 0.02 & 0.09 & 0.41 \\
\hline CFFe & 0.56 & 0.14 & 0.01 & 0.04 & 0.01 & 0.22 & 0.03 & 0.07 & 0.37 & 0 \\
\hline Mean CF & 0.15 & 0.06 & 0.07 & 0.01 & 0.14 & 0.68 & 0.01 & 0.02 & 0.1 & 0.78 \\
\hline PLI & 0.31 & 0.25 & 0.11 & 0.24 & 0.37 & 0.34 & 0.23 & 0.27 & 0.28 & 0.6 \\
\hline
\end{tabular}

Table 2: Computational Contamination Factors (CF) and Pollution Load Index (PLI).

The PLI value greater than 1 is polluted [18]. Therefore, the studied borehole water samples are not polluted with the studied heavy metals. This is in agreement with reports of Duru [13], who recorded low PLI $(<1)$ in borehole water samples obtained from the evacuated section of Orji mechanic village. However, significant PLI was recorded in sample $\mathrm{J}$ (0.60). Ranking the PLI in descending order were; $\mathrm{J}>\mathrm{E}>\mathrm{F}>\mathrm{A}>\mathrm{I}>\mathrm{H}>\mathrm{B}>\mathrm{D}>\mathrm{G}>\mathrm{C}$.

\section{Correlation coefficient matrix}

Spearman's correlation coefficient matrix between heavy metal concentrations in the borehole water samples at 5\% significance level were carried to check for inter-relationship between heavy metal concentrations. The coefficient simply tells us whether the sources of contamination of heavy metal are similar or dissimilar. The coefficient of relationship is presented in Table 3. All metals exhibited negative association/relationship with Iron, while positive relationship/ association was exhibited between other heavy metals. However, significant positive associations were exhibited between $\mathrm{Ni} / \mathrm{Cd}(0.66)$, $\mathrm{Ni} / \mathrm{Pb}$ (0.79), $\mathrm{Ni} / \mathrm{Cu}(0.99), \mathrm{Cd} / \mathrm{Cu}(0.62)$ and $\mathrm{Pb} / \mathrm{Cu}(0.78)$.

\begin{tabular}{|l|l|l|l|l|l|}
\hline Metals & $\mathbf{N i}$ & $\mathbf{C d}$ & $\mathbf{P b}$ & $\mathbf{C u}$ & $\mathbf{F e}$ \\
\hline $\mathbf{N i}$ & 1 & & & & \\
\hline $\mathbf{C d}$ & $\mathbf{0 . 6 6 0 0 1 1}$ & 1 & & & \\
\hline $\mathbf{P b}$ & $\mathbf{0 . 7 8 8 2 4 1}$ & 0.302702 & 1 & & \\
\hline $\mathbf{C u}$ & $\mathbf{0 . 9 8 5 5 4}$ & $\mathbf{0 . 6 1 5 3 7 4}$ & $\mathbf{0 . 7 7 5 8 5 1}$ & 1 & \\
\hline $\mathbf{F e}$ & -0.28353 & -0.09774 & -0.39599 & -0.1818 & 1 \\
\hline
\end{tabular}

*Numbers in bold are significant

Table 3: Correlation coefficient matrix between heavy metals.

When the coefficient is positive, the source of contamination of the positively associated metals is similar while negative coefficients suggest different/dissimilar sources of contamination. The contamination source is mainly from auto-mechanic waste, agricultural activities and waste dumpsites. These sources pollute groundwater through leaching. Other notable contamination could be through storage tanks and pipes that transport the water from the ground to the surface. The tanks and pipes are made from materials rich in heavy metals such as Iron, Copper and Lead etc.

\section{Water Quality Index (WQI)}

Water Quality Index (WQI) was calculated based on the heavy metals studied with a view of determining the suitability of borehole water for human consumption. WQI gives a single number which characterizes the overall quality of the water. WQI was computed using equation (3).

$$
W Q I=\frac{\sum_{i=1}^{n} q_{i} \cdot W_{i}}{\sum_{i=1}^{n} W_{i}}
$$

Where, $\mathrm{W}_{\mathrm{i}}=$ weightage factor (calculated from equation (5)), which were 0.103 for $\mathrm{Ni}, 0.683$ for $\mathrm{Cd}, 0.205$ for $\mathrm{Pb}, 0.002$ for $\mathrm{Cu}, 0.007$ for $\mathrm{Fe}$ respectively $\left(\sum \mathrm{W}_{\mathrm{i}}=1\right) ; \mathrm{K}=$ constant value and it is calculated using equation (4).

$$
\mathrm{K}=\frac{1}{\sum\left(\begin{array}{l}
1 \\
\mathrm{~S}_{\mathrm{i}}
\end{array}\right)}
$$

Where, $\mathrm{S}_{\mathrm{i}}=$ standard value of the $\mathrm{i}^{\text {th }}$ water quality parameter; $\mathrm{n}=$ total number of water quality parameters.

$$
\mathrm{W}_{\mathrm{i}}=\mathrm{K} / \mathrm{S}_{\mathrm{i}}(5)
$$

Where, $\mathrm{q}_{\mathrm{i}}=$ quality rating for the $\mathrm{i}^{\text {th }}$ water quality parameter and is calculated using the equation (6).

$$
\mathrm{q}_{\mathrm{i}}=\mathrm{C}_{\mathrm{m}} / \mathrm{S}_{\mathrm{i}} \times 100(6)
$$

The computed WQI for the borehole water samples is presented in Figure 3. The judgment for WQI is given by Ramakrishnaiah [19], which is Excellent Water Quality (EWQ) (when WQI $<50$ ), Good Water Quality (GWQ) (when $50<\mathrm{WQI} \leq 100$ ), Poor Water Quality (PWQ) (when $100<\mathrm{WQI} \leq 200$ ), Very Poor Water Quality (VPWQ) (when $200<\mathrm{WQI} \leq 300$ ) and Unsuitable for Drinking (UnSFD) (when WQI $>300)$. 
Page 5 of 9

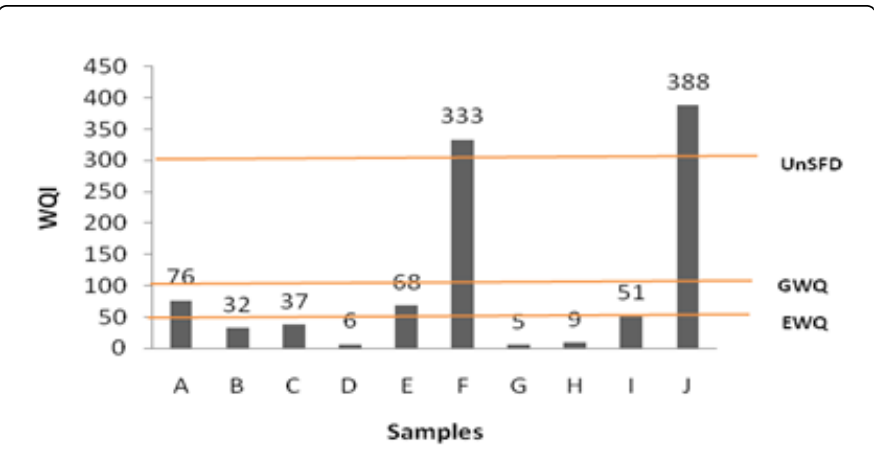

Figure 3: Computed WQI for the borehole water samples.

The WQI generally showed EWQ to GWQ except for samples F and $J$ which showed that water is UnSFD. The borehole water samples F and $J$ are located in an environment where high anthropogenic activities are experienced such as automechanic activities and the presence of a market. The environment could be responsible for the unsuitability of these samples based on the heavy metals studied. Other WQI obtained showed EWQ for B (32), C (37), D (6), G (5), and H (9) respectively while GWQ was obtained for A (76), E (68) and I (51) respectively. The mean WQI obtained in the present study is (100.5) suggesting PWQ, which is in agreement with study conducted by Duru who recorded PWQ (WQI=153.33) for borehole water samples collected from evacuated section of Orji MV.

\section{pH variations in studied borehole water samples over 12 weeks}

The variations in $\mathrm{pH}$ over 12 weeks are presented in Figure 4. The NAFDAC and SON recommended a permissible limit of 6.3-8.5 and 6.5-8.5 respectively for $\mathrm{pH}$ in drinking water in Nigeria.

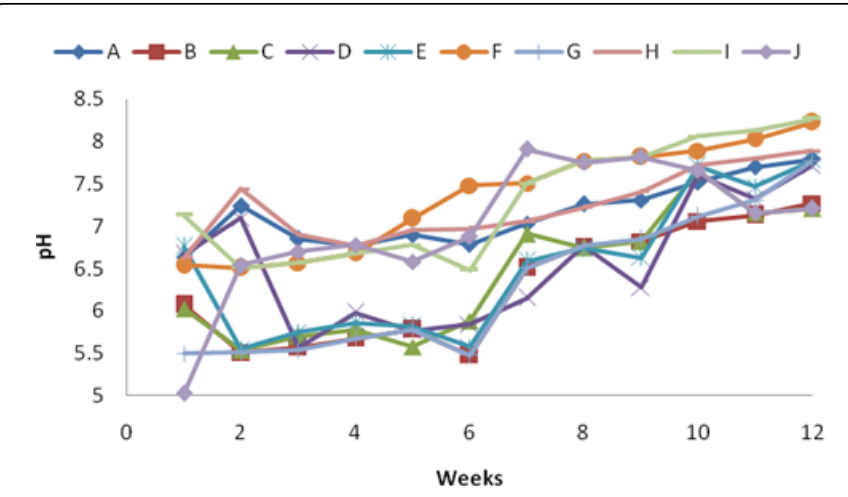

Figure 4: $\mathrm{pH}$ variations in studied borehole water samples (August 2017 - October 2017).

After 12 weeks of study, all samples were still within standard range of (6.3/6.5-8.5). Prolong storage will cause the $\mathrm{pH}$ value to exceed the threshold limit. However, individual $\mathrm{pH}$ values range were $\mathrm{A}$ (6.63-7.79), B (5.51-7.27), C (5.54-7.21), D (5.57-7.72), E (5.55-7.78), F (6.51-8.23), G (5.50-7.77), H (6.63-7.89), I (6.51-8.27) and J (5.03-7.21) respectively. One factor ANOVA showed no significant difference in $\mathrm{pH}$ variations over the 12 weeks for the different samples $(\mathrm{p}<0.05)$. Generally, our study showed an increase of the $\mathrm{pH}$ value, in stored water samples. Our results are in contrast to decreasing $\mathrm{pH}$ values in stored harvested rainwater obtained by Achadu [20] and groundwater in rural Morrocco by Douhri [21], but in agreement with previous studies of Duru [22] and Prescott [23]. This may be related to the bacterial development and activity. Microorganisms often change their environmental $\mathrm{pH}$ by producing acidic or basic metabolic wastes [24]. Therefore, the microorganisms here tend to produce more basic metabolic waste as $\mathrm{pH}$ tends to be more basic/alkaline with storage (Figure 4). Drinking water with high $\mathrm{pH}$ could lead to the condition known as alkalosis. Alkalosis can cause arrhythmia or irregular heartbeats, imbalanced electrolyte levels and coma. In addition, World Health Organization [24] stated that drinking water with an elevated $\mathrm{pH}>11$ can cause skin, eye and mucous membrane irritation [25].

\section{pH variability over the study period}

The variability was calculated as the $\mathrm{CV}(\%) . \mathrm{CV}$ is useful in comparing the degree of variation from data series to another by measuring dispersion of a probability distribution or frequency distribution. The CV was calculated mathematically by simply dividing the standard deviation by mean, represented by equation (7),

\section{CV $(\%)=$ Standard deviation/Mean $\times 100(7)$}

They were categorized as little variation $(\mathrm{CV} \%<20)$, moderate variation $(\mathrm{CV} \%=20-50)$ and high variation $(\mathrm{CV}>50)[26]$. The $\mathrm{CV}$ was calculated for the sampling points and weeks. The computed variability is represented in Figures $5 a$ and $5 b$. The computed CV (\%) for the points and weeks simply tells us how the $\mathrm{pH}$ of the borehole water is distributed around Orji with respect to storage over 12 weeks.
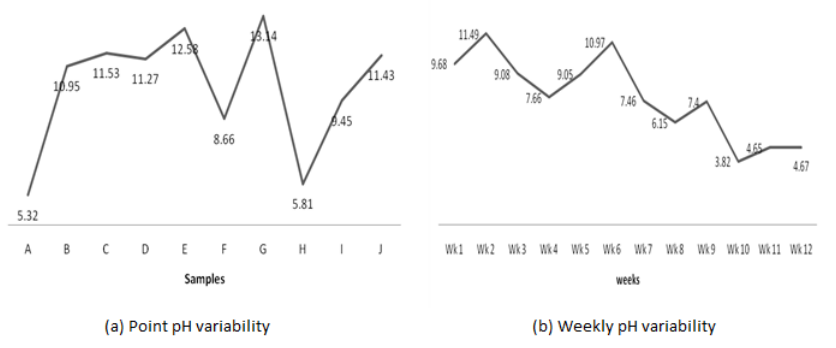

Figure 5: (a-b): The Coefficient of Variations (\%) for $\mathrm{pH}$ over the study period.

The variability were generally low $(<20 \%)$ for both points and weekly variations in $\mathrm{pH}$. The only obvious reason for the low variability could be due to the sample points having similar latitude and longitude. Low variability has been recorded by Prescott [23]. However, the least variability was recorded at A (5.32\%) while the highest was recorded at G (13.40) represented in Figure 5a. In Figure $5 \mathrm{~b}$, the lowest variability was recorded in week $10(3.82 \%)$ while the highest recorded in week 2 (11.49\%). High variability indicates rapid microbial activity.

\section{Linear relationship between heavy metals and $\mathrm{pH}$ values}

The LRM establishes linear relationship/associations between two variables. The model gives out the linear equation showing the slope and intercepts as well as regression coefficient ( $\mathrm{R}^{2}$ value). Regression coefficients represent the mean change in the response variable for one unit of change in the predictor variable while holding other predictors 
Citation: Enyoh CE, Verla AW, Egejuru NJ (2018) pH Variations and Chemometric Assessment of Borehole Water in Orji, Owerri Imo State,

Page 6 of 9

in the model constant. The constant variable is the concentrations of the studied metals while the predictor variables are the $\mathrm{pH}$ values. This statistical control that regression provides is important because it isolates the role of one variable from all of the others in the model. $\mathrm{R}^{2}$ value shows how strong the linear relationship is. A value of 1 means a perfect positive relationship and a value of zero means no relationship at all while -1 means a perfect negative relationship. The linear regression relationship between the concentration of studied metals $(\mathrm{Ni}, \mathrm{Cd}, \mathrm{Cr}, \mathrm{Pb}, \mathrm{Cu}, \mathrm{Fe})$ and the $\mathrm{pH}$ values from week 1 to 12 are presented in Figures 6-9. In general the relationship/association between $\mathrm{pH}$ values and heavy metal concentrations were low $(<0.5)$, which could be due to the $\mathrm{pH}$ of the water samples being more basic/ alkaline. Since acidic water indicates possible corrosion problems resulting from dissolution/leaching of metals such as Copper, Zinc and Cadmium that can be toxic as well as Lead [27]. The New York State Department of Health explains that Lead exposure can lead to a host neurological and reproductive problem, such as seizures, hearing loss and miscarriages.
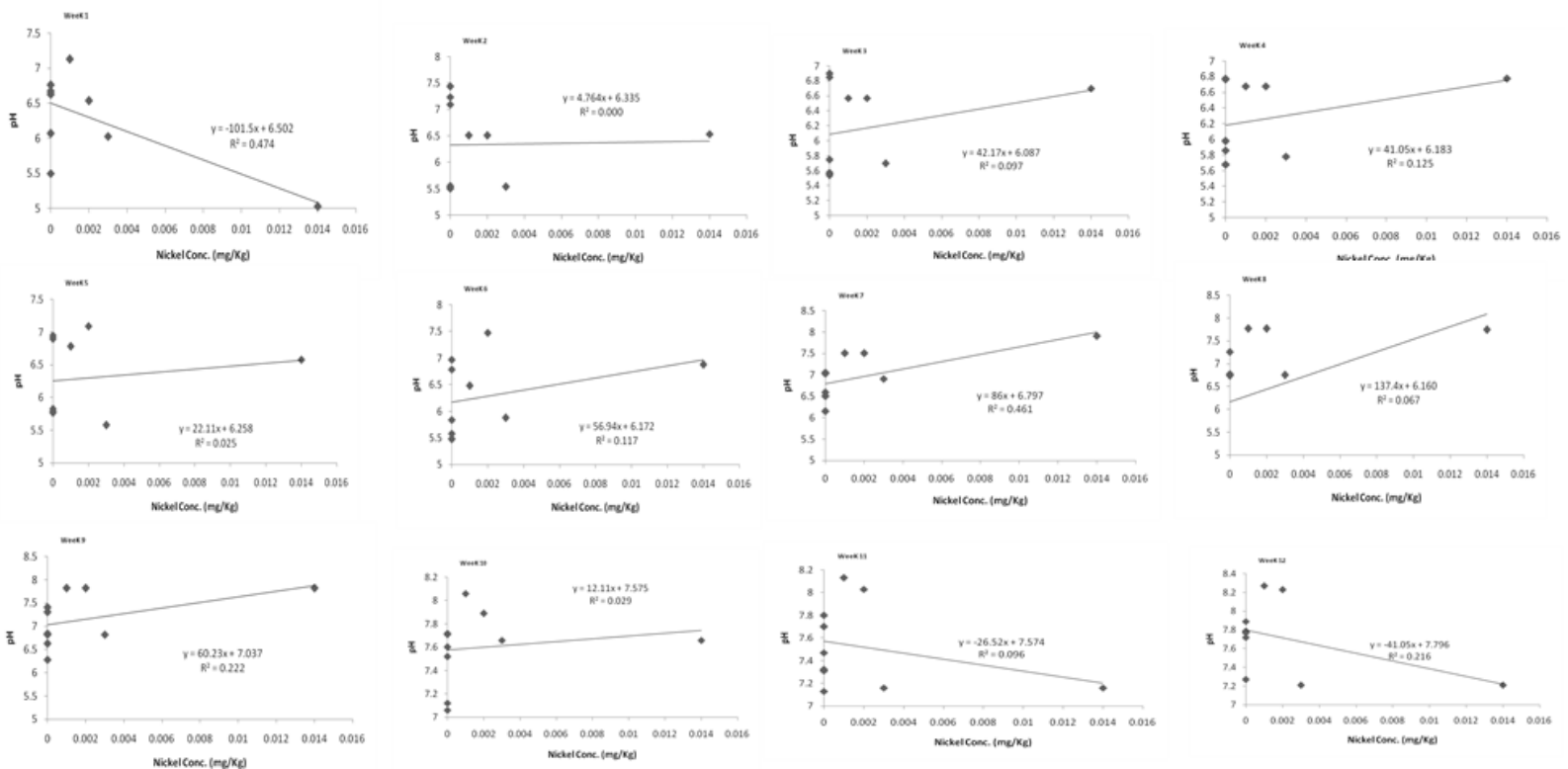

Figure 6: Linear regression relationship between $\mathrm{pH}$ variations and Nickel (Ni) concentrations from week 1 to 12 of the study.

The regression coefficients $\left(\mathrm{R}^{2}\right.$ value) for the linear regression analysis between the variations in $\mathrm{pH}$ and Nickel concentration $(\mathrm{pH} / \mathrm{Ni})$ were positive. There was no relationship/association for $\mathrm{pH} / \mathrm{Ni}$ during week two. The order of significant relationship is week 1

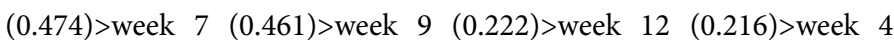
$(0.125)>$ week $6 \quad(0.117)>$ week $3(0.097)>$ week $11(0.096)>$ week 8 $(0.067)>$ week $10(0.029)>$ week $5(0.025)>$ week $2(0.000)$ respectively. 
Citation: Enyoh CE, Verla AW, Egejuru NJ (2018) pH Variations and Chemometric Assessment of Borehole Water in Orji, Owerri Imo State,

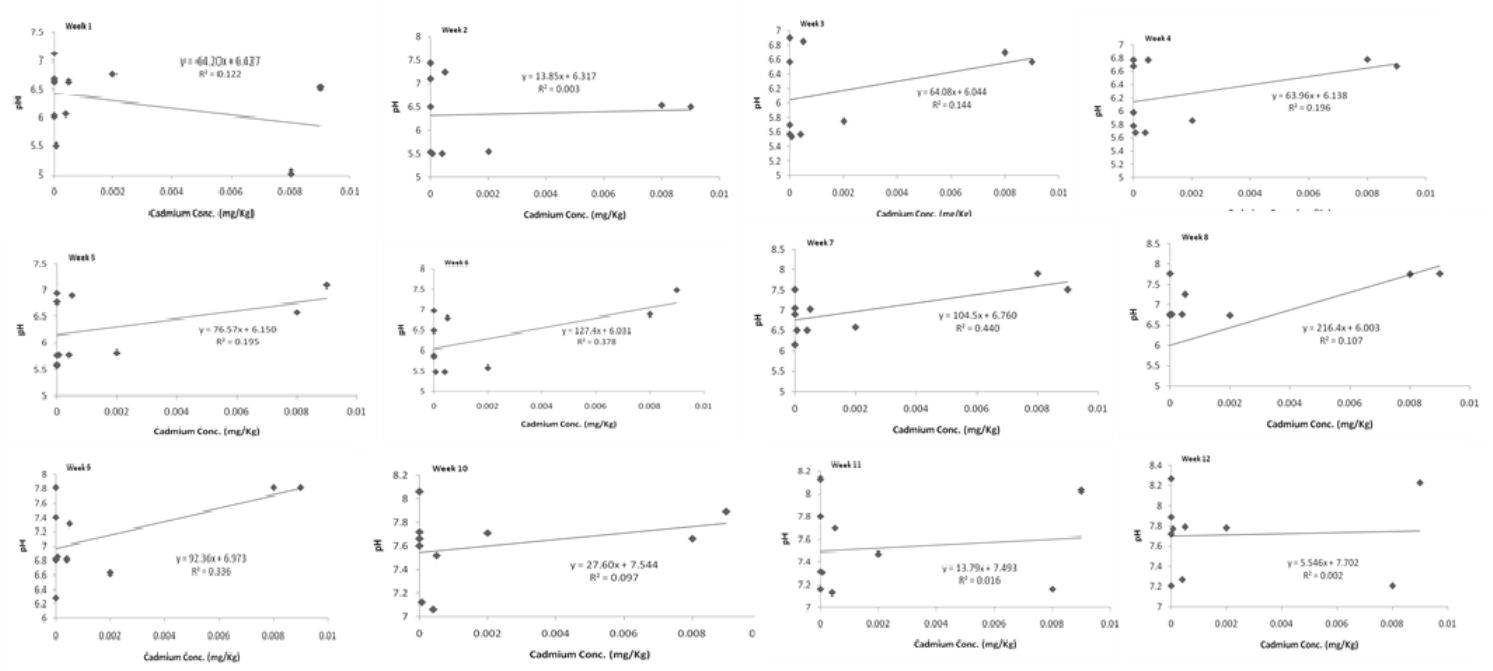

Figure 7: Linear regression relationship between $\mathrm{pH}$ variations and Cadmium $(\mathrm{Cd})$ concentrations from week 1 to 12 of the study.

The linear regression relationship between $\mathrm{pH}$ variations and Cadmium concentrations from week 1 to 12 of the study is presented in Figure 7. The relationship between $\mathrm{pH} / \mathrm{Cd}$ were in the order of $\begin{array}{llll}\text { decreasing significance; week } 7 & (0.440)>\text { week } & 6 & (0.378)>\text { week }\end{array}$

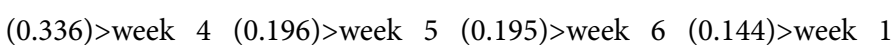
$\begin{array}{lllll}(0.122)>\text { week } & 8 & (0.107)>\text { week } 10 & (0.097)>\text { week } 11 & (0.016)>\text { week } 2\end{array}$ $(0.003)>$ week $12(0.002)$.
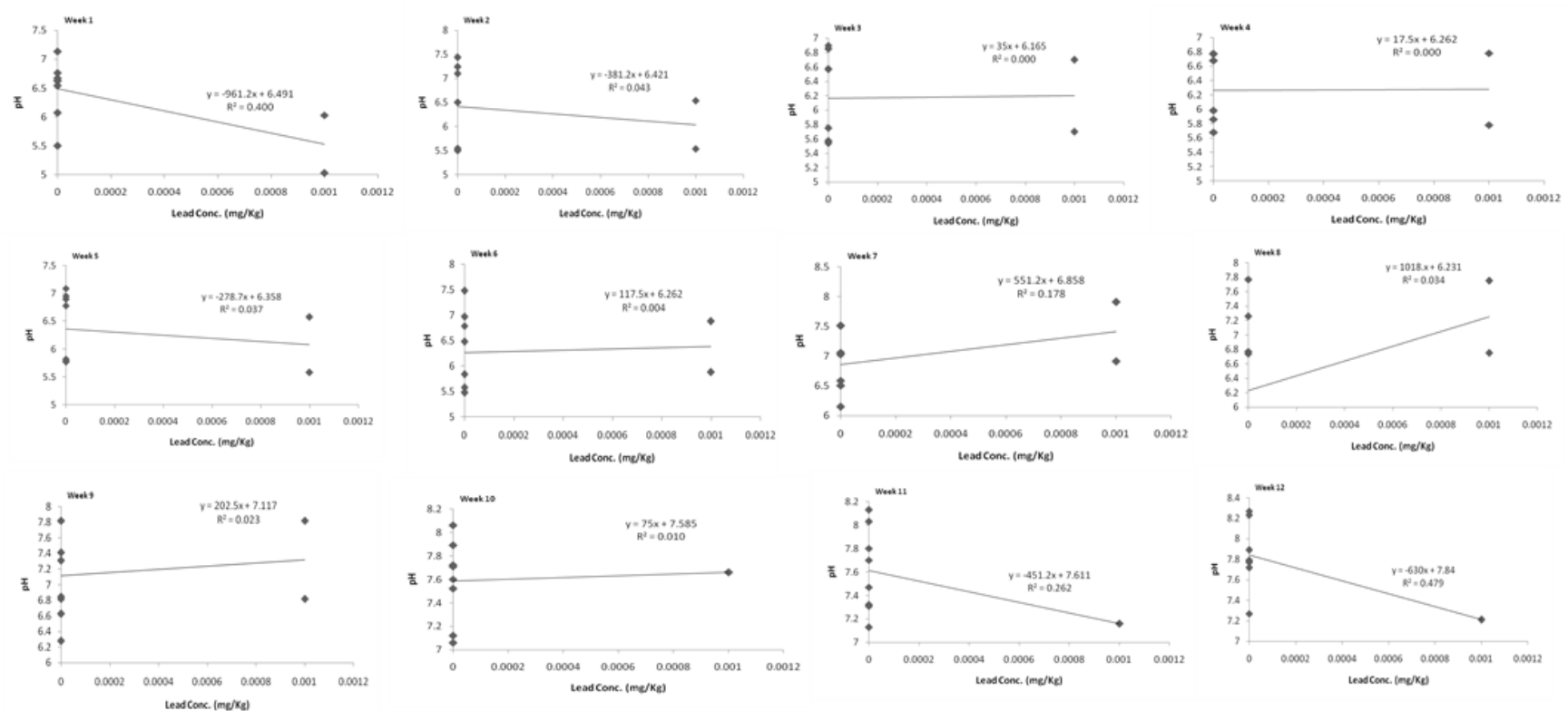

Figure 8: Linear regression relationship between $\mathrm{pH}$ variations and Lead $(\mathrm{Pb})$ concentrations from week 1 to 12 of the study.

The linear regression relationship between $\mathrm{pH}$ variations and Lead concentrations from week 1 to 12 of the study is presented in Figure 8. The relationship between $\mathrm{pH} / \mathrm{Pb}$ were in the order of decreasing significance; week $12(0.479)>$ week $1(0.400)>$ week $11(0.262)>$ week 7

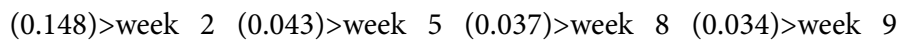
$(0.023)>$ week $6(0.004)>$ week 3 and $4(0.000)$. There was no relationship in week 3 and 4 . 


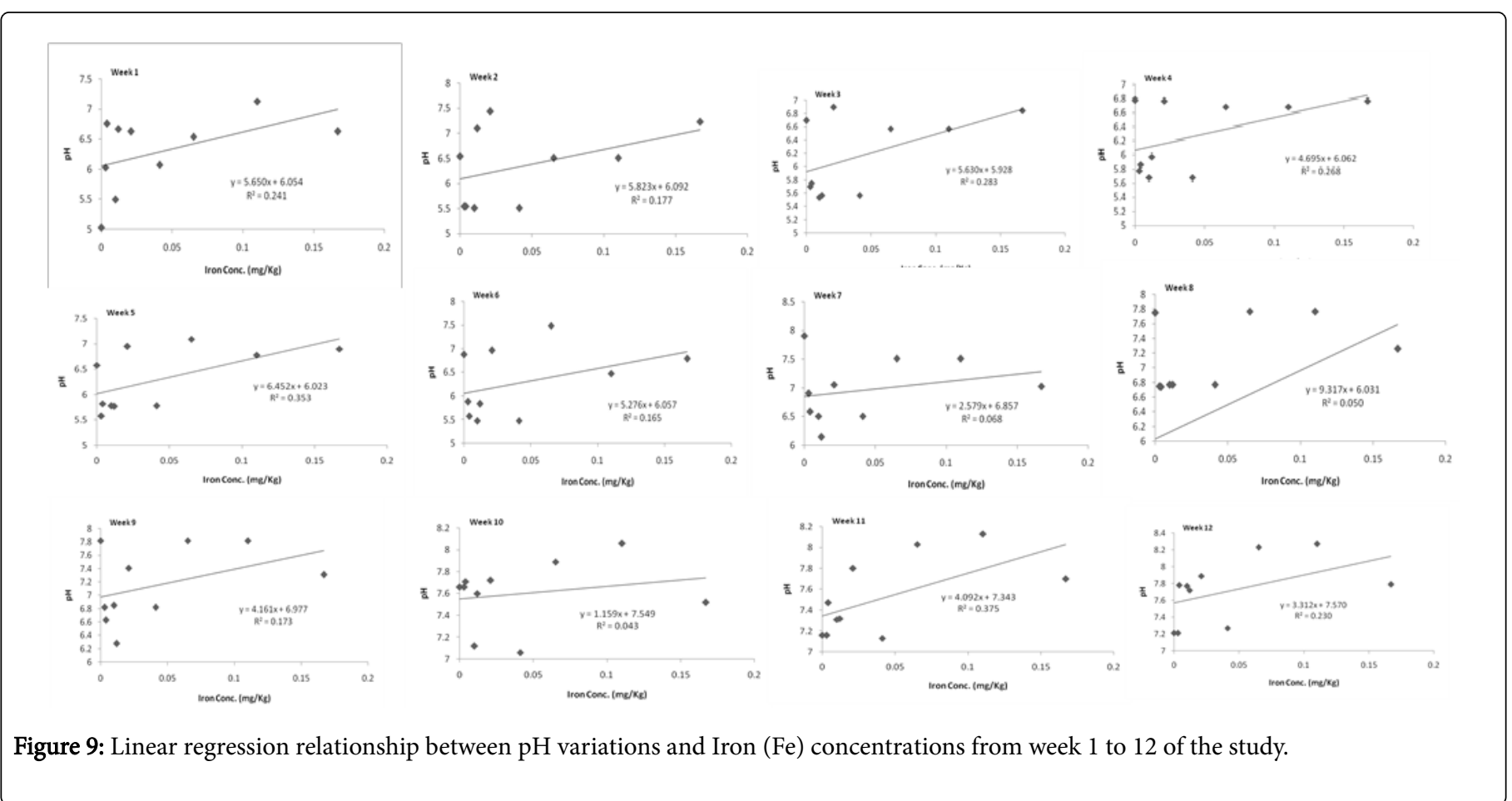

The linear regression relationship between $\mathrm{pH}$ variations and Iron concentrations from week 1 to 12 of the study is presented in Figure 9. The relationship between $\mathrm{pH} / \mathrm{Fe}$ were in the order of decreasing significance; week $11(0.375)>$ week $5(0.353)>$ week $3(0.283)>$ week 4

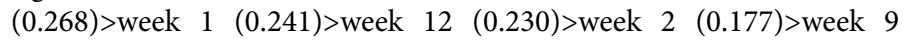

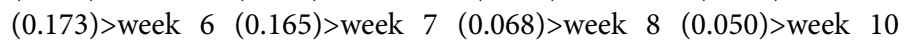
(0.043) respectively.

The mean regression coefficient between $\mathrm{pH}$ and heavy metals is presented in Figure 10. The plot is showing which of the metal is most associated with the $\mathrm{pH}$ values recorded over 12 weeks. The most relationship is recorded by Iron $(0.202)$ followed by Cadmium $(0.169)$, then Nickel (0.161) and Lead (0.123).

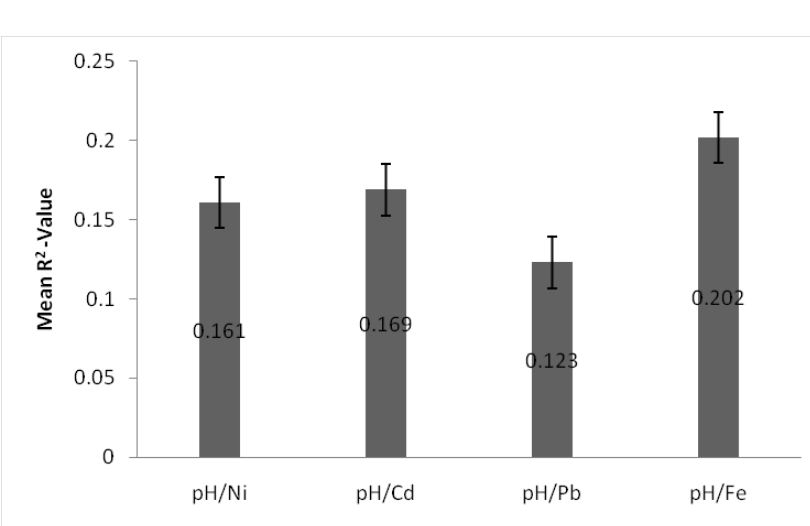

Figure 10: The mean regression coefficient with error bars between $\mathrm{pH}$ and heavy metals.

\section{Conclusion}

The study has shown that the continuous house storage of borehole will increase the values of $\mathrm{pH}$. Although, over 12 weeks, the $\mathrm{pH}$ didn't exceed the permissible limit $(6.3 / 6.5-8.5)$ set by NAFDAC/SON. The mean metal concentrations were also below the threshold limit set by SON, indicating that the borehole water samples is not yet contaminated by these metals. However, elevated concentrations of Cadmium above the threshold limit were recorded in some samples. The low metal concentration could be due to the $\mathrm{pH}$ of the water samples being more basic/alkaline with prolong storage, since acidic water could have caused dissolution/leaching of these metals from pipes, tanks etc. into the water. Chemometric assessment such as linear regression analysis revealed positive association between $\mathrm{pH}$ values and metal concentration. Ranking the association in order of significant $\mathrm{pH} / \mathrm{Fe} \quad(0.202)>\mathrm{pH} / \mathrm{Cd} \quad(0.169)>\mathrm{pH} / \mathrm{Ni} \quad(0.161)>\mathrm{pH} / \mathrm{Pb}$ $(0.123)$ respectively. There was generally low variability $(<20)$ for point and weekly distributions. Spearman's correlation revealed metal contaminations were from similar source(s). Only Fe showed different source(s) from other metals studied. CF showed low contamination $(<1)$, except for Cadmium which showed moderate to considerable contamination. PLI showed no pollution $(<1)$, WQI revealed EWQ to UnSFD. In addition, mean WQI revealed PWQ with WQI of 100.5. Therefore, precaution should be taken when consuming borehole water from Orji based on the studied metals.

\section{References}

1. Okorie PU (2017) The Challenges of Declining Freshwater Resources. Paper Presented at the World Environment Day Conference held at Imo state University Owerri, Nigeria.

2. Timothy RG, Makoto T, Henk K, Jason JG, Diana MA (2011) Beneath the surface of global change: Impacts of climate change on groundwater. Journal of Hydrology 405: 532-560. 
Citation: Enyoh CE, Verla AW, Egejuru NJ (2018) pH Variations and Chemometric Assessment of Borehole Water in Orji, Owerri Imo State, Nigeria. J Environ Anal Chem 5: 238. doi:10.4172/2380-2391.1000238

Page 9 of 9

3. Onigbogi O, Ogunyemi O (2014) Effect of Storage Containers on Quality of Household Drinking Water in Urban Communities in Ibadan, Nigeria. International Journal of Public Health Science 3: 253-258.

4. Nigeria Bereau of Statistics (2016) Water Supply Statistics.

5. Trevett AF, Carter RC, Tyrrel SF (2004) Water quality deterioration: A study of household drinking water quality in rural Honduras. International Journal of Environmental Health Research 14: 273-283.

6. Hoque BA, Hallman K, Levy J, Bouis H, Ali N, et al. (2006) Rural drinking water at supply and household levels: Quality and management. International Journal of Hygiene and Environmental Health 209: 451-460.

7. McGarvey ST, Buszin J, Reed H, Smith DC, Rahman Z, et al. (2008) Community and household determinants of water quality in coastal Ghana. Journal of Water and Health 6: 339-349.

8. Kausar S, Maann AA, Zafar MI, Ali T (2012) A Study of storage system for drinking water and its health impacts at household level in Punjab, Pakistan. Pakistan Journal of Nutrition 11: 591-595.

9. Corapcioglu MO, Huang CP (1987) The Adsorption of Heavy Metals onto Hydrous Activated Carbon. Journal of Water Research 21: 1031-1044.

10. Issabayeva G, Aroua MK, Sulaiman NM (2008) Continuous adsorption of lead ions in a column packed with palm shell activated carbon. Journal Hazard Material 155: 109-113.

11. Schwartz BS, Hu H (2007) Adult lead exposure: time for change. Journal of Environmental Health Perspective 115: 451-453.

12. Pelfrêne A, Waterlot C, Mazzuca M, Nisse C, Cuny D, et al. (2012) Bioaccessibility of trace elements as affected by soil parameters in smelter-contaminated agricultural soils: A statistical modeling approach. Environmental Pollution 160: 130-138.

13. Duru CE, Okoro IP, Enyoh CE (2017) Quality Assessment of Borehole Water within Orji Mechanic Village Using Pollution and Contamination Models. International Journal of Chemistry, Material and Environmental Research (IJCMER) 4: 123-130.

14. Agency for Toxic Substances and Disease Registry (1997) Toxicology profile for used mineral based crankcase oil. U.S. Department of Health and Human Services, Public Health Service Press, Atlanta, GA, USA.

15. International Chemometrics Society (2006) Definitions.

16. Ibe FC, Isiukwu BO, Enyoh CE (2017) Trace metals analysis of soil and edible plant leaves from abandoned municipal waste dumpsite in Owerri,
Imo state, Nigeria. World News of Natural Sciences (WNOFNS) 13: 27-42.

17. Verla EN, Verla AW, Enyoh CE (2017) Pollution assessment models of surface soils in Port Harcourt city, Rivers State, Nigeria. World News of Natural Sciences (WNOFNS) 12: 1-20.

18. Thomilson DC, Wilson DJ, Harris CR, Jeffrey DW (1980) Problems in the assessment of heavy metal levels in estuaries and the formation of pollution index. Helgol Wiss Meeresunlter 33: 566-575.

19. Ramakrishnaiah CR, Sadashivaiah C, Ranganna G (2009) Assessment of water quality index for the groundwater in Tumkur Taluk, Karnataka State, India. E-J Chem 6: 523-530.

20. Achadu OJ, Ako FE, Dalla CL (2013) Quality Assessment of Stored Harvested Rainwater in Wukari, North-Eastern Nigeria: Impact of Storage Media. IOSR Journal of Environmental Science, Toxicology and Food Technology 7: 25-32.

21. Douhri H, Raissouni I, Tazi S, Douhri B (2015) Effect of House Storage on Water's Quality in Rural Areas of Tangier-Tetuan Region (Morocco). Larhyss Journal 24: 301-314.

22. Duru CE, Amadi US, Enyoh CE (2017) Storage and its Effect on Chemical Quality Indicators in Sachet Water Brands Sold in Owerri Municipal, Imo State, Nigeria. World News of Natural Sciences (WNOFNS) 12: 73-81.

23. Prescott LM, Harley JP, Klein DA (1999) The influence of environmental factors on growth. Microbiology, 4th edn. McGraw-Hill Companies, Inc., USA, pp. 123-132.

24. World Health Organization (2006) Guidelines for Drinking Water Quality - incorporating first Addendum to 3rd edn. 1: Recommendation.

25. Verla EN, Verla AW, Ugwulor L (2015) Seasonal variation of heavy metals in playgrounds of public schools within Owerri metropolis, Imo State, Nigeria. International Letters of Chemistry, Physics and Astronomy 50: 61-70.

26. Nweke MO, Ukpai SN (2016) Use of enrichment, ecological risk and contamination factors with geoaccumulation indexes to evaluate heavy metal contents in the soils around Ameka mining area, south of Abakaliki, Nigeria. Journal of Geography, Environment and Earth Science International 5: 1-13.

27. Livestrong (2017) Health Effects of $\mathrm{pH}$ on Drinking Water. 